\title{
PENGARUH MODEL PEMBELAJARAN DISCOVERY LEARNING TERHADAP HASIL BELAJAR MATEMATIKA SISWA PADA MATERI BANGUN RUANG SISI DATAR
}

\author{
Anintya Putri Wahyuni ${ }^{1)}$ \\ Abdul Basir Abbas ${ }^{2)}$ \\ Kukuh ${ }^{3)}$ \\ ${ }^{1), 2), 3)}$ Program Studi Pendidikan Matematika, Universitas Mulawarman \\ ${ }^{(*)}$ Email: anintyaputriw@gmail.com
}

\begin{abstract}
ABSTRAK
Discovery Learning merupakan suatu model pembelajaran yang menekankan pentingnya pemahaman struktur terhadap suatu disiplin ilmu, melalui keterlibatan siswa secara aktif dalam proses pembelajaran. Jenis penelitian ini adalah eksperimen semu, yang bertujuan untuk mengetahui ada atau tidak adanya pengaruh hasil belajar matematika siswa yang diajar menggunakan model pembelajaran Discovery Learning pada materi bangun ruang sisi datar di kelas VIII SMP Negeri 14 Samarinda tahun ajaran 2017/2018. Populasi dalam penelitian ini adalah seluruh siswa kelas VIII SMP Negeri 14 Samarinda, yang terdiri dari 7 kelas. Teknik yang digunakan dalam pengambilan sampel adalah Purposive Cluster Sampling, dengan sampel terdiri dari 2 kelas, yaitu kelas VIIE dengan model pembelajaran Discovery Learning sebagai eksperimen dan kelas VIID dengan model pembelajaran langsung sebagai kontrol. Pengumpulan data dengan melakukan observasi dan tes hasil belajar matematika berupa soal uraian. Teknik analisis data yang digunakan dalam penelitian ini adalah statistik deskriptif dan statistik inferensial dengan taraf signifikan pengujian sebesar 5\%. Berdasarkan hasil penelitian, terdapat perbedaan hasil belajar matematika siswa yang diajar menggunakan model pembelajaran Discovery Learning dan Pembelajaran Langsung sehingga terdapat pengaruh model pembelajaran Discovery Learning terhadap hasil belajar matematika siswa pada materi bangun ruang sisi datar siswa kelas VIII SMP Negeri 14 Samarinda tahun ajaran 2017/2018.
\end{abstract}

Kata kunci: Discovery Learning, Model Pembelajaran.

\begin{abstract}
Discovery Learning is a learning model that emphasizes the importance of understanding the structure of a scientific discipline, through active student involvement in the learning process. This reseach was a quasi-experiment, which aims to determine whether the Discovery Learning learning model affects mathematics learning outcomes for flat-sided building materials in class VIII SMP Negeri 14 Samarinda in the 2017/2018 academic year. The population of this study was all students of class VIII
\end{abstract}

Pengaruh Model Pembelajaran Discovery Learning Terhadap Hasil Belajar Matematika Siswa Pada Materi Bangun Ruang Sisi Datar 
SMP Negeri 14 Samarinda, which consisted of 7 classes. The sampling technique was purposive cluster sampling, with a sample consisting of 2 classes, i.e. class VIIE with the Discovery Learning learning model as experimental class and class VIID with direct learning model as control class. The data collected came from observations and tests of mathematics learning outcomes i.e. description questions. Data analysis technique used in this research was descriptive statistics and inferential statistics with a significant level of $5 \%$. Based on research, there are differences in learning outcomes of students who are taught math using model Discovery Learning and Learning Direct. Thus, there is an effect of the Discovery Learning learning model on students' mathematics learning outcomes on the flat-side room building material of class VIII students of SMP Negeri 14 Samarinda in the 2017/2018 academic year.

Keywords: Discovery Learning, Learning Model

\section{PENDAHULUAN}

Sumber daya manusia yang berkualitas merupakan salah satu modal penting dalam pembangunan bangsa Indonesia untuk dapat bertahan di tengah tengah kompleksitas zaman. Salah satu cara untuk meningkatkan kualitas sumber daya manusia adalah melalui pendidikan. Pendidikan menjadi sarana yang penting dalam pengembangan sumber daya manusia. Sumber daya manusia yang berkualitas dan mampu bersaing dapat dihasilkan melalui pendidikan. Salah satu tujuan pendidikan adalah menyiapkan peserta didik menjadi anggota masyarakat yang memiliki kemampuan akademik atau professional yang dapat menerapkan dan mengembangkan ilmu pengetahuan.

Dalam pendidikan, kegiatan belajar dan mengajar merupakan kegiatan yang paling pokok. Hal ini berarti bahwa berhasil tidaknya pencapaian tujuan pendidikan banyak tergantung kepada bagaimana proses belajar mengajar yang dirancang dan dijalankan secara professional. Guru dituntut mampu mewujudkan proses belajar mengajar dapat bermanfaat maksimal serta dengan mudah tersampaikan dan diharapkan seorang siswa cepat menyelesaikan wajib belajar dan mandiri untuk masa depannya nanti.

Pembelajaran matematika adalah suatu kegiatan untuk memperoleh pengetahuan yang dibangun oleh siswa sendiri dan harus dilakukan sedemikian rupa sehingga dapat memberikan kesempatan kepada siswa untuk menemukan kembali konsep-konsep matematika. Pembelajaran matematika sebaiknya dimulai dari masalah-masalah kontekstual atau realistik kehidupan, dekat dengan alam pikiran siswa dan relevan dengan masyarakat agar mempunyai nilai manusiawi. Dengan demikian, pembelajaran matematika sesuai dengan ciri-ciri matematika itu sendiri yaitu adanya alur penalaran yang logis dan memiliki pola pikir deduktif yang konsisten.

Dalam kegiatan belajar mengajar yang sering ditemui, masih banyak kegiatan pembelajaran didominasi oleh guru dan sangat sedikit melibatkan siswa, sehingga sebagian besar siswa lebih memilih menerima begitu saja apa yang disampaikan guru, tanpa ada rasa

116 Pengaruh Model Pembelajaran Discovery Learning Terhadap Hasil Belajar Matematika Siswa Pada Materi Bangun Ruang Sisi Datar

Anintya Putri Wahyuni - Abdul Basir Abbas - Kukuh 
keingintahuan untuk mengkaji lebih jauh materi yang diajarkan. Selain itu, proses pembelajaran di sekolah kurang meningkatkan kreativitas siswa, terutama dalam pembelajaran matematika karena masih banyak guru yang menggunakan metode konvensional secara monoton dalam kegiatan pembelajaran di kelas.

Berdasarkan hasil wawancara dengan guru bidang studi matematika SMP Negeri 14 Samarinda yang dilakukan oleh peneliti diperoleh bahwa nilai matematika siswa jauh dari nilai KKM yaitu 75. Rendahnya hasil belajar siswa disebabkan oleh sebagian siswa yang tidak menyukai pelajaran matematika dikarenakan mereka mengalami kesulitan untuk memahami materi yang ada pada pelajaran matematika dibandingkan dengan materi pelajaran yang lainnya.

Keberhasilan proses pembelajaran tidak terlepas dari kemampuan guru dalam mengembangkan model-model pembelajaran yang berorientasi pada peningkatan intensitas keterlibatan siswa secara efektif didalam proses pembelajaran. Pengembangan model pembelajaran yang tepat pada dasarnya bertujuan untuk menciptakan kondisi pembelajaran yang memungkinkan siswa dapat belajar secara aktif dan menyenangkan sehingga siswa dapat meraih hasil belajar dan prestasi belajar yang optimal (Aunurrahman, 2012:37).

Penemuan (discovery) merupakan suatu model pembelajaran yang menekankan pentingnya pemahaman struktur atau ide-ide penting terhadap suatu disiplin ilmu, melalui keterlibatan siswa secara aktif dalam proses pembelajaran. Model pembelajaran ini dalam peranan guru adalah menyatakan persoalan, kemudian membimbing siswa untuk menemukan penyelesaian dari persoalan itu dengan perintah-perintah atau dengan lembar kerja. Siswa mengikuti petunjuk dan menemukan sendiri penyelesaiannya.

Peneliti menggunakan model pembelajaran discovery learning karena ada beberapa alasan yaitu siswa dapat berpartisipasi aktif dalam pembelajaran yang disajikan, materi yang dipelajari dapat mencapai tingkat kemampuan yang tinggi dan lebih lama membekas karena siswa dilibatkan dalam proses menemukannya.

Materi yang dipilih dalam penelitian ini adalah bangun ruang sisi datar. Alasannya karena bangun ruang sisi datar ini termasuk dalam salah satu materi dalam geometri ruang. Geometri ruang merupakan pelajaran matematika yang bersifat abstrak. Selain itu pada materi ini siswa masih banyak yang kesulitan untuk menjelaskan rumus luas permukaan dan volume dari berbagai bentuk bangun ruang sisi datar. Kesulitan tersebut disebabkan oleh banyaknya rumus yang harus dihapal oleh siswa. Kebanyakan guru berasumsi bahwa bila hapal rumus maka siswa pasti mampu mengerjakan soal. Bila berasumsi demikian berarti metode yang digunakan hanya menghafal dan memberikan tugas. Pembelajaran seperti ini tidak mengakar pada permasalahan yang dihadapi siswa, sehingga pembelajaran tidak bermakna. Siswa tidak paham bagaimana rumus itu ditemukan, dan bagaimana menerapkannya. 
Hamdani

(2011:185)

mengemukakan bahwa Discovery (penemuan) adalah proses mental ketika siswa mengasimilasikan suatu konsep atau suatu prinsip. Adapun proses mental misalnya, mengamati, menjelaskan, mengelompokkan, membuat kesimpulan, dan sebagainya. Sedangkan prinsip misalnya, setiap logam apabila dipanaskan memuai. Murid yang terlatih dengan discovery learning akan mempunyai skill dan teknik dalam pekerjaannya lewat problem-problem nyata di dalam lingkungannya. Menurut Kurniasih \& Sani (2014:110) discovery learning sebagai proses pembelajaran yang terjadi bila materi pembelajaran tidak disajikan dalam bentuk finalnya, tetapi diharapkan siswa mengorganisasi sendiri dan menemukan konsep melalui serangkaian data atau informasi yang diperoleh melalui pengamatan atau percobaan. Menurut Andriantoni dan Nurdin (2016 : 214) Discovery merupakan model pembelajaran yang melibatkan berbagai proses mental untuk menemukan suatu pengetahuan (konsep dan prinsip) yang dimiliki siswa. Dalam pembelajaran Discovery, siswa didorong untuk aktif belajar dengan konsep-konsep dan prinsip-prinsip bagi diri mereka sendiri. Menurut Kosasih (2013 :83) model pembelajaran penemuan (Discovery Learning) mengarahkan siswa untuk dapat menemukan sesuatu melalui proses pembelajaran yang dilakoninya. Siswa diraih untuk terbiasa menjadi seorang saintis (ilmuwan). Mereka tidak hanya sebagai konsumen, tetapi diharapkan pula bisa berperan aktif. Sedangkan menurut Trianto (dalam
Andriantoni dan Nurdin, 2016:212) pembelajaran Discovery bertujuan untuk memberikan cara bagi siswa membangun kecakapan-kecakapan intelektual (kecakapan berpikir) terkait dengan proses-proses berpikir reflektif. Dengan demikian, berarti siswa telah terpancing untuk mengeluarkan ide-ide ketika guru mengajukan suatu masalah. Hal tersebut akan membawa pikiran siswa untuk melakukan eksperimen dan mengumpulkan data.

Pembelajaran Discovery memiliki langkah-langkah yang sistematis, yakni sebagai berikut: (1) merumuskan masalah; (2) membuat jawaban sementara (hipotesis); (3) mengumpulkan data; (4) perumusan kesimpulan; dan (5) mengomunikasikan. Kelemahan dari pembelajaran Discovery dapat diatasi oleh guru dengan membentuk kelompok belajar dan dibantu dengan lembar kerja peserta didik (LKPD) yang dirancang agar mengarah ke tujuan pembelajaran dan memilih topik yang tidak begitu luas.

Proses pembelajaran matematika di SMP Negeri 14 Samarinda masih menggunakan pembelajaran langsung dimana guru yang berperan aktif saat proses pembelajaran mengakibatkan siswa bersikap pasif dalam belajar. Sehingga susah tercapai tujuan pembelajaran matematika. Suprijono (2009:46) menyatakan bahwa pembelajaran langsung atau direct instruction dikenal dengan sebutan active teaching. Dimana guru terlibat aktif dalam mengusung isi pelajaran kepada peserta didik dan mengajarkannya secara langsung kepada seluruh kelas. Menurut Killen (dalam Sanjaya, 2011:179)

118 Pengaruh Model Pembelajaran Discovery Learning Terhadap Hasil Belajar Matematika Siswa Pada Materi Bangun Ruang Sisi Datar

Anintya Putri Wahyuni - Abdul Basir Abbas - Kukuh 
pembelajaran langsung adalah satu pendekatan mengajar yang menekankan kepada proses penyampaian materi secara verbal dari seorang guru kepada sekelompok siswa dengan maksud siswa dapat menguasai materi pelajaran secara optimal. Siswa tidak dituntut untuk menemukan materi itu, melainkan materi pelajaran seakan-akan sudah jadi. Sedangkan menurut Arends (dalam Trianto, 2007:41) pembelajaran langsung adalah salah satu pendekatan mengajar yang dirancang khusus untuk menunjang proses belajar siswa yang berkaitan dengan pengetahuan deklaratif dan pengetahuan prosedural yang terstruktur dengan baik yang dapat diajarkan dengan pola kegiatan yang bertahap atau selangkah demi selangkah. Pembelajaran langsung adalah suatu model pengajaran yang berpusat pada guru dan memerlukan proses pembelajaran yang terstruktur dengan baik, pada proses pelaksanaannya, guru memberikan uraian jelas dan memberikan kesempatan siswa yang berlatih.

\section{METODE PENELITIAN}

Penelitian ini merupakan penelitian eksperimen yang bersifat eksperimen semu (quasi experimental) yaitu metode penelitian yang digunakan untuk mencari pengaruh perlakuan tertentu terhadap yang lain dimana peneliti tidak dapat mengontrol semua variabel-variabel luar yang mempengaruhi pelaksanaan eksperimen (Sugiyono, 2013:114). Variabel bebas dalam penelitian ini adalah variabel eksperimen yang karakteristiknya diyakini dapat menghasilkan pengaruh terhadap hasil belajar. Dalam hal ini hasil belajar sebagai variabel terikat.

Tabel 1. Rancangan Penelitian

\begin{tabular}{|c|c|c|}
\hline Kelompok & Perlakuan & Post test \\
\hline$(\mathrm{R})_{\mathrm{E}}$ & $\mathrm{X}$ & $\mathrm{O}_{1}$ \\
\hline$(\mathrm{R})_{\mathrm{K}}$ & - & $\mathrm{O}_{2}$ \\
\hline
\end{tabular}

(sumber: Modifikasi Sugiyono, 2013:116)

Penelitian ini menggunakan dua kelas dan masing-masing kelas diberi perlakuan berbeda. Kelas pertama menggunakan model pembelajaran Discovery Learning, dan kelas kedua menggunakan model pembelajaran konvensional. Jenis desain yang digunakan pada penelitian ini adalah Posttest-Only Control Grup Design. Rancangan penelitian Posttest-Only Control Grup Design ditunjukkan pada Tabel 1. Dimana $(\mathrm{R})_{\mathrm{E}},(\mathrm{R})_{\mathrm{K}}, \mathrm{X}, \mathrm{O}_{1}$ dan $\mathrm{O}_{2}$ masing-masing menyatakan kelompok eksperimen, kelompok kontrol, perlakuan kelompok eksperimen, tes hasil akhir belajar yang diberikan kepada kelompok eksperimen, dan tes hasil akhir belajar yang diberikan kepada kelompok kontrol.

Penelitian ini dilaksanakan pada April sampai Mei 2018 di kelas VIII SMP Negeri 14 Samarinda semester II tahun ajaran 2017/2018 yang berlokasi di Jalan Irigasi Kelurahan Rawa Makmur Kecamatan Palaran Kota Samarinda. Populasi pada penelitian ini adalah seluruh siswa kelas VIII SMPN 14 Samarinda tahun ajaran 2017/2018 yang terdiri dari 7 kelas dan berjumlah 252 siswa. Sampel dalam penelitian ini dipilih kelas dengan membentuk satu kelas sebagai kelas eksperimen dan satu kelas sebagai kelas kontrol. Kedua kelas 
tersebut memiliki kemampuan yang relatif sama. Sampel ditentukan dengan menggunakan teknik purposive cluster sampling. Instrumen yang digunakan penelitian ini berupa latihan soal dan tes hasil belajar.

\section{HASIL PENELITIAN DAN PEMBA- HASAN}

Analisis deskriptif berdasarkan nilai akhir untuk kelas eksperimen dengan model pembelajaran Discovery Learning $(D L)$ dan kelas kontrol dengan pembelajaran langsung disajikan dalam Tabel 2.

Tabel 2. Deskripsi Data Tes Hasil Belajar

\begin{tabular}{|l|l|l|l|l|}
\hline Model & Mean & sd & Min & Maks \\
\hline DL & 71,80 & 10,26 & 53,58 & 88,00 \\
\hline Langsung & 62,71 & 12,52 & 37,67 & 80,83 \\
\hline
\end{tabular}

Analisis inferensi dalam penelitian ini adalah uji t, namun dilakukan uji normalitas dan uji homogenitas terlebih dahulu sebagai uji asumsinya. Uji normalitas dilakukan untuk mengetahui apakah data yang akan diuji berdistribusi normal atau tidak. Berdasarkan hasil analisis data tentang uji normalitas menggunakan SPSS 21 diperoleh taraf signifikan statistik Kolmogorov-Smirnov untuk kelas eksperimen yang diajar dengan model pembelajaran Discovery Learning dan kelas kontrol yang diajar dengan model pembelajaran langsung sebesar 0,200. Oleh karena taraf signifikan statistik Kolmogorov-Smirnov lebih dari taraf signifikan pengujian, yaitu 0,200 > 0,05 maka belum cukup bukti untuk menolak $\mathrm{H}_{0}$. Ini berarti data tes hasil belajar matematika dari kedua kelompok berasal dari populasi yang berdistribusi normal.

Uji asumsi selanjutnya adalah uji homogenitas. Pemeriksaan kehomogenan digunakan untuk mengetahui apakah variansi dari perlakuan homogen atau tidak. Berdasarkan hasil analisis data tentang uji homogenitas data menggunakan SPSS 21 diperoleh taraf signifikan statistik uji Lavene's sebesar 0,228 . Oleh karena taraf signifikan statistik uji Lavene's lebih dari taraf signifikan pengujian, yaitu $0,228>0,05$ maka belum cukup bukti untuk menolak $\mathrm{H}_{0}$. Ini berarti data tes hasil belajar matematika untuk kedua kelompok berasal dari populasi dengan variansi yang homogen.

Setelah mengetahui bahwa data nilai tes hasil belajar matematika berdistribusi normal dengan variansi yang homogen, maka dilakukan uji hipotesis. Berdasarkan hasil analisis data, tentang uji $t$ menggunakan SPSS 21. Diperoleh taraf signifikansi $t$ sebesar 0.001 . Oleh karena taraf signifikansi $t$ kurang dari taraf signifikansi pengujian yaitu $0,001<$ 0,050, maka ditolak, yang berarti terdapat perbedaan hasil belajar matematika siswa yang diajar menggunakan model pembelajaran Discovery Learning dan Pembelajaran Langsung sehingga dapat disimpulkan bahwa terdapat pengaruh model pembelajaran Discovery Learning terhadap hasil belajar matematika pada materi bangun ruang sisi datar siswa kelas VIII SMPN 14 Samarinda tahun ajaran 2017/2018.

Hasil yang signifikan ini disebabkan bahwa dengan penggunaan model

120 Pengaruh Model Pembelajaran Discovery Learning Terhadap Hasil Belajar Matematika Siswa Pada Materi Bangun Ruang Sisi Datar

Anintya Putri Wahyuni - Abdul Basir Abbas - Kukuh 
pembelajaran Discovery Learning merupakan salah satu bagian dari pembelajaran discovery yang banyak melibatkan siswa dalam kegiatan belajar mengajar, namun dalam proses penemuan siswa mendapat bantuan atau bimbingan dari guru, agar mereka lebih terarah sehingga baik proses pelaksanaan pembelajaran maupun tujuan yang dicapai terlaksana dengan baik. Proses pembelajaran teryata berpengaruh terhadap hasil belajar siswa. Dengan pemberian model tersebut, dapat menimbulkan terjadinya interaksi dalam kegiatan belajar mengajar. Interaksi tersebut dapat juga terjadi antara siswa dengan siswa, siswa dengan bahan ajar, siswa dengan guru, dan siswa dengan bahan ajar dan guru. Interaksi dapat pula dilakukan antara siswa baik dalam kelompok-kelompok kecil maupun kelompok besar (kelas). Dalam melakukan aktivitas atau penemuan dalam kelompok-kelompok kecil, siswa berinteraksi satu dengan yang lain interaksi ini dapat dapat berupa saling sharing atau siswa yang lemah bertanya dan dijelaskan oleh siswa yang lebih pandai. Kondisi semacam ini selain akan berpengaruh pada penguasaan siswa terhadap materi matematika, juga akan dapat meningkatkan social skill siswa, sehingga interaksi merupakan aspek penting dalam pembelajaran matematika. Secara bersama-sama siswa dapat menyelesaikan masalah yang dihadapi. Secara keseluruhan interaksi tersebut dapat terjadi dengan menggunakan model pembelajaran Discovery Learning ini, kemungkinan konstruksi pengetahuan akan menjadi lebih besar dan kemungkinan untuk siswa dapat sampai pada kesimpulan yang diharapkan, serta pemahaman siswa akan tertanam dalam benak siswa dalam jangka waktu yang relatif lama.

Pelaksanaan pembelajaran di kelas kontrol menggunakan pembelajaran konvensional, siswa disini tidak aktif, mereka cenderung hanya mendengarkan dan menerima informasi yang diberikan oleh guru. Kesempatan untuk bermain dan mengganggu teman pada saat proses belajar sangat banyak. Karena siswa hanya mendengarkan penjelasan dari guru yang membuat mereka bosan. Siswa tidak serius mengerjakan tugas yang diberikan dan cenderung mencontek teman sebangkunya pada saat mengerjakan tugasnya. Siswa hanya aktif membuat catatan yang menyebabkan belajar hanya menghafal saja sehingga siswa sulit untuk mengerti dan mengakibatkan proses pembelajaran kurang efektif dan belum maksimal. Hal ini sesuai dengan hasil penelitian yang dilakukan oleh Siti Cholifatul Indah (2015) yang menunjukkan bahwa ada pengaruh model pembelajaran discovery learning terhadap keaktifan dan hasil belajar matematika siswa kelas VIII MTs Negeri Karangrejo, dan penelitian yang dilakukan oleh Sirna Dinata dkk (2016) yang menunjukkan bahwa terdapat pengaruh model discovery learning terhadap hasil belajar siswa kelas XI SMK Negeri 3 Rambah Kabupaten Rokan Hulu tahun pembelajaran 2015/2016. Serta penelitian yang juga dilakukan oleh Ni Nyoman Sri Budi Satyawati (2012) yang menunjukkan bahwa hasil belajar matematika siswa yang mengikuti pelajaran dengan model 
pembelajaran penemuan terbimbing berbasis LKS lebih baik daripada hasil belajar matematika siswa yang mengikuti pelajaran dengan model pembelajaran konvensional.

\section{KESIMPULAN}

Berdasarkan hasil penelitian dan pembahasan terdapat perbedaan hasil belajar matematika siswa yang diajar menggunakan model pembelajaran Discovery Learning dan Pembelajaran Langsung maka penulis menyimpulkan bahwa terdapat pengaruh model pembelajaran Discovery Learning terhadap hasil belajar matematika pada materi bangun ruang sisi datar siswa kelas VIII SMP Negeri 14 Samarinda tahun ajaran 2017/2018.

\section{DAFTAR PUSTAKA}

Adriantoni, dan Nurdin, S. (2016). Kurikulum dan pembelajaran. Jakarta: Raja Grafindo Persada.

Aunurrahman. (2010). Belajar dan Pembelajaran. Bandung: Alfabeta.

Hamdani. (2011). Strategi Belajar Mengajar. Bandung: Pustaka Setia.

Kosasih. (2014). Strategi Belajar dan Pembelajaran Implementasi Kurikulum 2013. Bandung: Yrama Widya.

Kurniasih, dan Sani, B. (2014). Sukses Mengimplementasikan Kurikulum 2013. Jakarta: Kata Pena.

Majid, A. (2013). Strategi Pembelajaran. Bandung: Remaja Rosdikarya.

Sanjaya, W. (2011). Strategi pembelajaran Berorientasi Standar Proses Pendidikan. Jakarta: Kencana.
Suprijono, A. (2009). Cooperative Learning (Teori Aplikasi PAIKEM). Yogyakarta: Pustaka Pelajar.

Sugiyono. (2013). Metode Penelitian Pendidikan Pendekatan Kuantitatif, Kualitatif, dan $R \& D$. Bandung: Alfabet.

Trianto. (2007). Model-Model Pembelajaran Inovatif Berorientasi Konstruktivistik. Jakarta: Prestasi Pustaka.

Trianto. (2009). Mendesain Model Pembelajaran Inivatif-Progresif Konsep, Landasan, dan Implementasinya pada Kurikulum Tingkat satuan Pendidikan (KTSP) . Jakarta: Kencana

122 Pengaruh Model Pembelajaran Discovery Learning Terhadap Hasil Belajar Matematika Siswa Pada Materi Bangun Ruang Sisi Datar

Anintya Putri Wahyuni - Abdul Basir Abbas - Kukuh 